\title{
Nett Present Value (NPV) analysis for projection of feasibility of Coastal Sand Dune Tourism in Parangtritis Village
}

\author{
Dicky Satria Dwiputra ${ }^{1,{ }^{*},}$ Yan Abdi Rahmanu ${ }^{1}$, Atikarosa Sih Tofani ${ }^{1}$, Muhammad Naufal ${ }^{1}$, \\ Khansa Sitostratufana Arsy An Nisa ${ }^{1}$, Jundi Muhammad Bariq ${ }^{1}$, and Ratih Fitria Putri ${ }^{1}$ \\ ${ }^{1}$ Geography and Environmental Science, Department of Environmental Geography, Faculty of Geography, \\ Universitas Gadjah Mada, Indonesia
}

\begin{abstract}
Sand dune in Parangtritis Village has a speciality of being formed in humid climates (tropical). The initiation of Barchan Sand Dune as a new tourism based on eco-tourism has to consider many aspects to maintain sustainability of sand dune. It needs some information on economic valuation to determine the capacity of tourism objects as a consideration of sand dune's sustainability. The purpose of this research is to know the projection of Barchan sand tourism's feasibility until 2045. The research method is the economic valuation approach by calculating Nett Present Value (NPV) as the analysis (cost) and the benefit earned by Barchan Sand Dune Tourism. The method of economic valuation is chosen because it is able to convert ecosystem services into currency value (IDR) so that it can be a valid comparator. The hypothesis in this study states that the feasibility of Barchan Sand Dune Tourism will increase until certain year, but the increased feasibility will cease in a certain year and decrease in the following year. The results are obtained based on the calculation of Nett Present Value (NPV), it shows positive value so that Barchan Sand Dune Tourism is feasible to continue until 2045 with estimated profit reached IDR648,000,000. The calculation results show a decrease in the level of tourism efficiency in 2017. The level of efficiency can be increased again through management optimization based on the characteristics of the tour, which are something to do, something to see and something to buy at Sand Dune Barchan.
\end{abstract}

\section{Introduction}

Sand dune is formed by a geomorphological process, it's grind or deformation of sand material by wind (aeolian). Sand dune has a variety of typologies, depending on the direction of the wind, one of it is barchan type. The emergence of sand dune in Parangtritis Village has a distinctness compared to other sand dune in the world because it has Barchan Sand Dune [1]. Barchan dunes generally do not appear isolated but instead belong to several kilometer long dune fields, forming corridors oriented along the wind direction. Within these corridors the dunes show rather well selected sizes and inter-dune spacing [2]. Barchan Sand Dune are usually formed in dry climates but it's also formed in the Parangtritis Village with a humid climate (tropical).

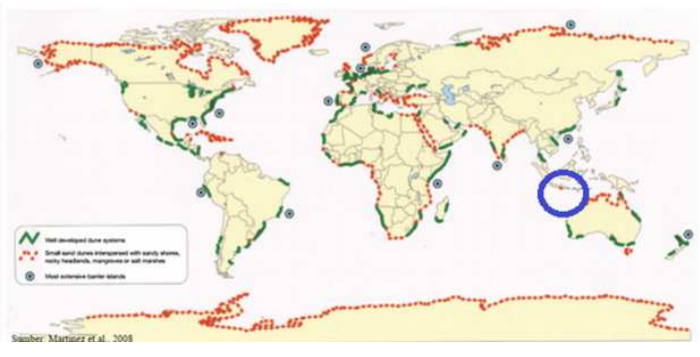

Fig. 1. The location of Sand Dune Barchan Parangtritis to distribution of coastal sand mound around the world [3].
The uniqueness of course has its own benefits, one of the benefits is from economic, the existence of environmental services that lead to the tourism sector so it can earn some profits. Lately it has developed a new tourism activity, like surfing the sand (sand boarding) which became one of young children's favorite [4]. The feasibility of Barchan Sand Dunes Tourism will increase until certain year because at the first, the additional value given for the activity will add benefit value, but after reaching a certain level, additional value for the same activity will no longer result in additional benefits and will be able to reduce the total benefits of the activity [5]. Ecotourism concept is one of the tourism base that emphasizes on the aspect of natural ecosystem wealth as an object as well as it's meant for tourist's education. The plan for the development of the ecotourism-based barchan sand dune has to consider the sustainability aspects of the sand dune and the sustainability of tourism projects to be developed. The sustainability of tourism projects can be identified through the economic valuation calculations of environmental services. The principle of economic valuation considers the value of the cost and benefits [6].

Cost Benefit Analysis (CBA) is cash or cash equivalent that's spent for goods or services which's expected to provide current or future benefits for an organization [7]. The Cost Benefit Analysis (CBA) approach can be used as a basis for policy

* Corresponding author: dicky.satria.dwiputra@mail.ugm.ac.id 
recommendations by calculating total costs in the form of money [8]. According to Siegel \& Shimp (1994), cost and benefit analyzes can be used to analyze the feasibility of government projections with benefits from community [9]. One method of cost and benefit analysis is using the Net Present Value (NPV) method. Net Present Value (NPV) is the simplest analytical technique. In addition, NPV is also one way of economic valuation analysis that takes into account the difference between the value of cost and the value of benefits to the large of interest [10].

The location of the study was at Gumuk Pasir Barchan in Regosembilan Hamlet, Parangtritis Village, Kretek District, Bantul, Yogyakarta Special Region. The sand dune found in Parangtritis is part of the sand dune that lies along the alluvial plains of the South coast of Java. The absence of research related to the economic valuation of barchan sand dune became one of the practical reasons for choosing the location and the theme of the study. Thus the purpose of this study is to determine the projection of sandstone tourism feasibility until the year 2045. Information on the economic valuation of sand dune is expected to help managers to know the sustainability capacity of sand dune tourism and realize sustainable tourism.

\section{Methods}

\subsection{Location and time of research}

The location of the study is in the Sand Dunes of Parangtritis located in the Regosembilan, Parangtritis Village, Kretek Sub-district, Bantul Regency. Geographically located at $110^{\circ} 18^{\prime} 58.5^{\prime \prime} \mathrm{E}$ and $8^{\circ} 1^{\prime} 0.4^{\prime \prime} \mathrm{S}$. The type of sand dunes in the location is barchan dunes with elevation 17-40 meters from sea level [11]. The location of the study is one of the results of the aeoalian geomorphology process. The typology of barchan dunes is quite rare and unique due to the sand dunes typologically formed in the desert region, but in Indonesia a tropical climate with high rainfall can be formed [12].

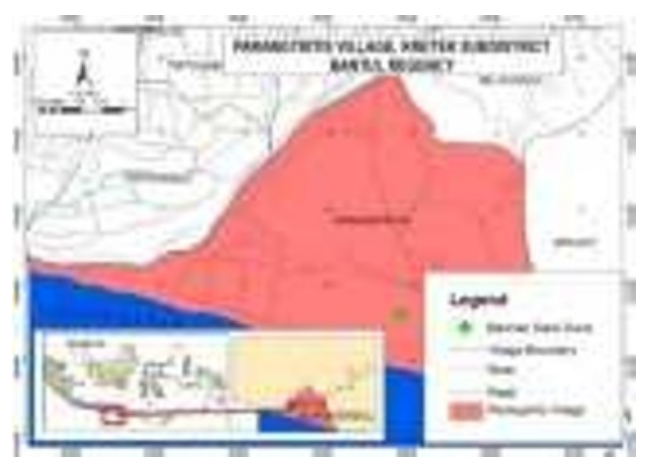

Fig. 2. Administrative map of Parangtritis Village. Source: Mutia, 2018.

The study was conducted from December 2017 to January 2018. The location of the study, Barchan Sand Dune was selected because the area is the core zone of sand dune that is conserved at the same time will be developed as ecoeduwisata based tourism project. Based on these aspects, barchan sand dune is very interesting to be studied especially in terms of consideration of the sustainability of tourism development projects.

\subsection{Methods}

The primary data used is from the results of depth interview with key informant which is manager of barchan sand dune area, aerial photos of Sand Barchan Gumuk, and field photo documentation. Data processing results in depth interview is done by calculating Nett Present Value (NPV) to analyze Cost Benefit Analysis (CBA) which determines the feasibility of Sand Gumuk Barchan tourism project until 2045. Calculation formula with Net Present Value (NPV) method is:

$$
\begin{aligned}
& \mathrm{NPV}=\sum_{t=0}^{n} \frac{B t-C t}{(1+r)^{t}} \quad \text { (1)NPV }= \\
& \sum_{\mathrm{t}=0}^{\mathrm{n}}\left(\frac{\mathrm{Bt}-\mathrm{Ct}}{(1+\mathrm{r})^{\mathrm{t}}}\right)(1) \text { Information: } \\
& B t=\text { Income or benefit in the year- } \\
& C t=\text { cost in year } \mathrm{t} \\
& r=\text { discount rate } \\
& n=\text { economic age } \\
& t=\text { year- }
\end{aligned}
$$

The value of the NPV shows that the benefit of an activity is greater than or equal to the cost. The NPV value of less than zero (negative) indicates that the cost used is greater than the profit earned so that projections or activities are declared in adequate [13].

\subsection{Flow chart}

Research includes preparation phase, data collection, data processing, and descriptive analysis of synthesis. The results of the analysis became the basis of the recommendations given in the study. Stages of research can be seen in Figure 3.

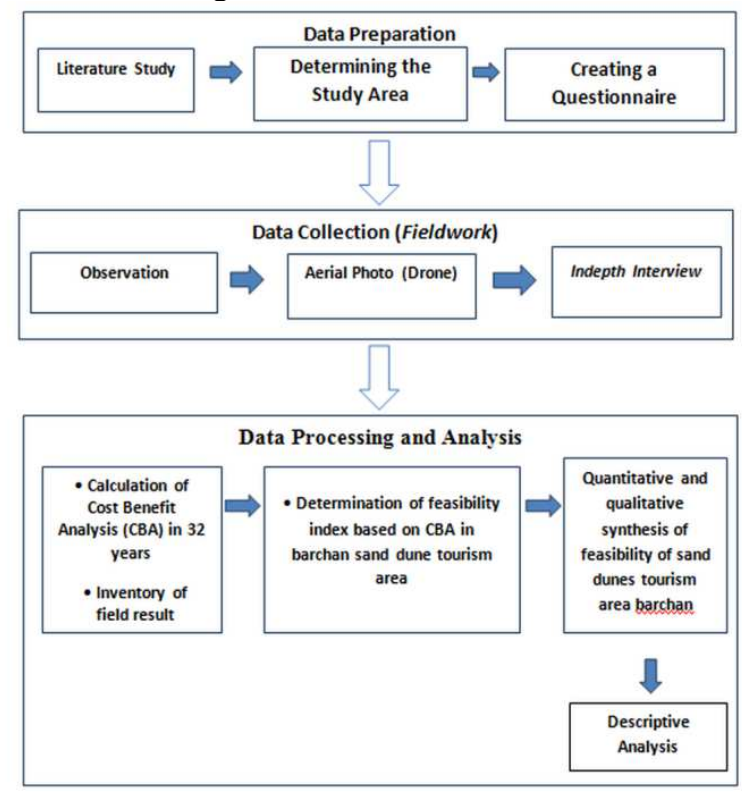

Fig. 3. Flow chart of the research. 


\section{Discussions}

The uniqueness and beauty of the Barchan Sand Dune is used as a new tourism location in Yogyakarta which is now an attraction for domestic and foreign tourists and continues to increase the number of tourists every year. Its location in an area with Parangtritis Beach becomes an advantage, so that tourists can reach the sand dune easily because of the availability of access road. Utilization of sand dune as tourism is managed in 2014 by the people of Regosembilan Hamlet, Parangtritis Village, Kretek District, Bantul Regency with the help of community its self. The initiation of barchan eco-tourism base is based on the development of illegal tourism in the core zone of sand dune that can damage the sustainability of barchan sand dune.

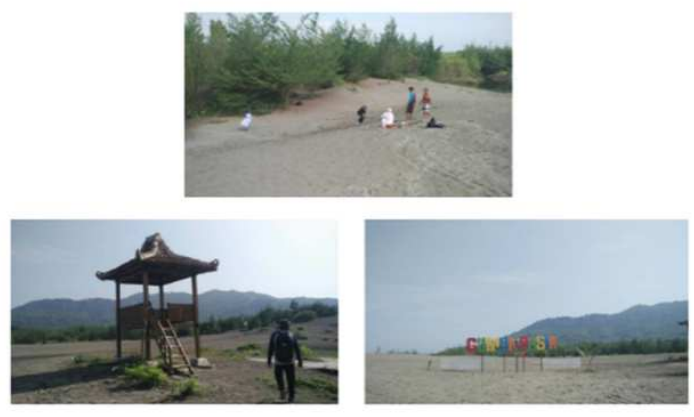

Fig. 4. Barchan Sand Dunes Tourism.

Source: Documentation of author, 2018.

The economic valuation to assess the feasibility of the eco-tourism development project of sand barchan tourism is done by using Cost Benefit Analysis (CBA) method. In CBA, only cash flows in and out of the organisation are considered [13]. The calculation of the feasibility of a development project considers costs and benefits with the assumption of a fixed value from the start of the project 2014 to 2045 . This method is chosen because measuring feasibility of the tourism development project continuation within the next 32 years from 2014 to 2045 adjusted to the target year towards Indonesia Gold.

The cost calculation of the project is from initial investment, it is self-supporting community amounting to IDR1,500,000 during the first two years of the project started (Table 1). Additional costs are incurred in the third year from electricity costs and spot maintenance costs for photos. The total price is the cost component price multiplied by 30 years because for the first two years it still uses the capital from the community selfhelp. The total price in the third year (2016) through the 32nd year (2045) will be used in the Net Present Value (NPV) calculation. In addition to the costs incurred, also consider the benefits (benefits) obtained from Barchan Sand Dune. The benefits are derived from parking feess and sand boarding rentals. Total results obtained from these benefits for 32 years is IDR648,000,000 (Table 2).
Table 1. Projection cost of Barchan Sand Dune for 32 years.

\begin{tabular}{|c|l|r|c|c|c|}
\hline No & $\begin{array}{l}\text { Cost } \\
\text { component }\end{array}$ & Cost/unit & $\begin{array}{c}\text { Capital in } \\
\text { 1 year }\end{array}$ & $\begin{array}{c}\text { Cost in 1 } \\
\text { year }\end{array}$ & $\begin{array}{c}\text { Total cost } \\
\text { in 32 years }\end{array}$ \\
\hline 1 & Capital & $1,500,000$ & $18,000,000$ & & $36,000,000$ \\
\hline 2 & Electricity & 200,000 & & $2,400,000$ & $72,000,000$ \\
\hline 3 & $\begin{array}{l}\text { Maintenance } \\
\text { cost }\end{array}$ & $1,000,000$ & & $12,000,000$ & $360,000,000$ \\
\hline & Total & $1,200,000$ & $18,000,000$ & $14,400,000$ & $468,000,000$ \\
\hline
\end{tabular}

Table 2. Projection benefit of Barchan Sand Dune for 32 years.

\begin{tabular}{|l|l|r|r|}
\hline No & Benefit component & $\begin{array}{c}\text { Benefit in 1 year } \\
\text { (IDR) }\end{array}$ & $\begin{array}{c}\text { Total benefit in } \\
\text { 32 years (IDR) }\end{array}$ \\
\hline 1 & Parking & $18,000,000$ & $540,000,000$ \\
\hline 2 & Sandboarding rentals & $3,600,000$ & $108,000,000$ \\
\hline Total & $21,600,000$ & $648,000,000$ \\
\hline
\end{tabular}

Based on the calculation of Cost Benefit Analysis, new revenue is obtained in the third year (2016), because the first two years is still in the stage of management and development of facilities and there is no cost component of existing benefits. The profit value earned from the difference in revenue costs can be used to calculate the NPV value. The determination of the feasibility of a projection is done by looking at the NPV value. An activity or projection is said to be feasible if the NPV value is greater than or equal to zero. The value of the NPV shows that the benefit of an activity is greater than or equal to the cost. The NPV value of less than zero indicates that the cost used is greater than the profit earned so that projections or activities are declared inadequate [14]. Net present value (NPV) is the difference between disbursement and disbursed income by using social opportunity cost of capital as a discount factor, or in other words, an estimated future cash flow discounted at this time. Methods that pay attention to the time value of money. Interest given to the tourist area of sand dune barchan is $10 \%$ in each year.

The feasibility of this development project is calculated economically and the result is seen in the NPV value. Based on the NPV calculation table (Table 3), for thirty two years, it is known that in the first year (2014) and second (2015) the NPV shows a negative value, while the second year (2015) to thirty two years NPV shows positive value. Negative values on NPV calculations indicate that the development project of barchan sand dune tourism area in the first year is not feasible because it has no benefit and income from tourism object. The second year to the 32 nd positive value of NPV which shows that the development project Barchan sand dune is feasible because it has advantages for tourism area barchan sandstone. 
Table 3. Calculation of NPV of

Barchan Sand Dune for 32 years

\begin{tabular}{|c|c|c|c|c|c|c|}
\hline Years & Benefit (Bt) & Cost $(\mathrm{Ct})$ & Bt-Ct & $\mathbf{r}$ & NPV & Feasible \\
\hline 2014 & 0 & $18,000,000$ & $-18,000,000$ & 0.1 & -16363636 & Unfeasible \\
\hline 2015 & 0 & $18,000,000$ & $-18,000,000$ & 0.1 & -14876033 & Unfeasible \\
\hline 2016 & $21,600,000$ & $14,400,000$ & $7,200,000$ & 0.1 & 5409466.6 & Feasible \\
\hline 2017 & $21,600,000$ & $14,400,000$ & $7,200,000$ & 0.1 & 4917696.9 & Feasible \\
\hline 2018 & $21,600,000$ & $14,400,000$ & $7,200,000$ & 0.1 & 4470633.5 & Feasible \\
\hline 2019 & $21,600,000$ & $14,400,000$ & $7,200,000$ & 0.1 & 4064212.3 & Feasible \\
\hline 2020 & $21,600,000$ & $14,400,000$ & $7,200,000$ & 0.1 & 3694738.5 & Feasible \\
\hline 2021 & $21,600,000$ & $14,400,000$ & $7,200,000$ & 0.1 & 3358853.1 & Feasible \\
\hline 2022 & $21,600,000$ & $14,400,000$ & $7,200,000$ & 0.1 & 3053502.9 & Feasible \\
\hline 2023 & $21,600,000$ & $14,400,000$ & $7,200,000$ & 0.1 & 2775911.7 & Feasible \\
\hline 2024 & $21,600,000$ & $14,400,000$ & $7,200,000$ & 0.1 & 2523556.1 & Feasible \\
\hline 2025 & $21,600,000$ & $14,400,000$ & $7,200,000$ & 0.1 & 2294141.9 & Feasible \\
\hline 2026 & $21,600,000$ & $14,400,000$ & $7,200,000$ & 0.1 & 2085583.5 & Feasible \\
\hline 2027 & $21,600,000$ & $14,400,000$ & $7,200,000$ & 0.1 & 1895985 & Feasible \\
\hline 2028 & $21,600,000$ & $14,400,000$ & $7,200,000$ & 0.1 & 1723622.8 & Feasible \\
\hline 2029 & $21,600,000$ & $14,400,000$ & $7,200,000$ & 0.1 & 1566929.8 & Feasible \\
\hline 2030 & $21,600,000$ & $14,400,000$ & $7,200,000$ & 0.1 & 1424481.6 & Feasible \\
\hline 2031 & $21,600,000$ & $14,400,000$ & $7,200,000$ & 0.1 & 1294983.3 & Feasible \\
\hline 2032 & $21,600,000$ & $14,400,000$ & $7,200,000$ & 0.1 & 1177257.5 & Feasible \\
\hline 2033 & $21,600,000$ & $14,400,000$ & $7,200,000$ & 0.1 & 1070234.1 & Feasible \\
\hline 2034 & $21,600,000$ & $14,400,000$ & $7,200,000$ & 0.1 & 972940.11 & Feasible \\
\hline 2035 & $21,600,000$ & $14,400,000$ & $7,200,000$ & 0.1 & 884491.01 & Feasible \\
\hline 2036 & $21,600,000$ & $14,400,000$ & $7,200,000$ & 0.1 & 804082.74 & Feasible \\
\hline 2037 & $21,600,000$ & $14,400,000$ & $7,200,000$ & 0.1 & 730984.31 & Feasible \\
\hline 2038 & $21,600,000$ & $14,400,000$ & $7,200,000$ & 0.1 & 664531.19 & Feasible \\
\hline 2039 & $21,600,000$ & $14,400,000$ & $7,200,000$ & 0.1 & 604119.26 & Feasible \\
\hline 2040 & $21,600,000$ & $14,400,000$ & $7,200,000$ & 0.1 & 549199.33 & Feasible \\
\hline 2041 & $21,600,000$ & $14,400,000$ & $7,200,000$ & 0.1 & 499272.12 & Feasible \\
\hline 2042 & $21,600,000$ & $14,400,000$ & $7,200,000$ & 0.1 & 453883.74 & Feasible \\
\hline 2043 & $21,600,000$ & $14,400,000$ & $7,200,000$ & 0.1 & 412621.58 & Feasible \\
\hline 2044 & $21,600,000$ & $14,400,000$ & $7,200,000$ & 0.1 & 375110.53 & Feasible \\
\hline 2045 & $21,600,000$ & $14,400,000$ & $7,200,000$ & 0.1 & 341009.57 & Feasible \\
\hline Total & $648,000,000$ & $468,000,000$ & $208,800,000$ & & 55753026.92 & \\
\hline
\end{tabular}

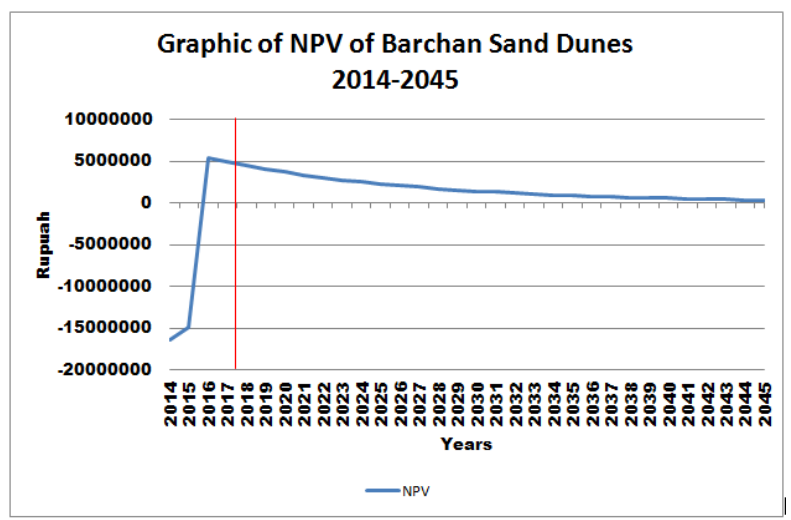

Fig. 5. Graphic of NPV of Barchan Sand Dune for 32 years.

Figure 5 shows that NPV is starting to has a positive value in 2016, then declining in the following years, and from 2017 to 2045 the value of NPV remains positive but the annual difference is not significant. This is caused by the longer the project is done then there is a decrease in the level of efficiency in the project. The more the year the production process will decrease and so will the income. However, the graph can be taken into consideration in developing the management of Barchan sand dune because the amount of net profit can be known and that will be obtained until the year 2045 .

The analysis related to projection of feasibility of barchan sand dunes tourism known that the tourism is feasible to continue until 2045 with the assumtion that neither spatial aspect nor management modal would not be the obstacles during 2014 until 2045 in the development of tourism. Based on the field observation and indepth interview on both of sand dunes manager and the tourist as can be seen in Figure 6, the efforts and the innovations are needed to maintain the sustainability of tourism activity and to improve the tourist's interest to visit the barchan sand dunes while maintaining the environmental sustainability.

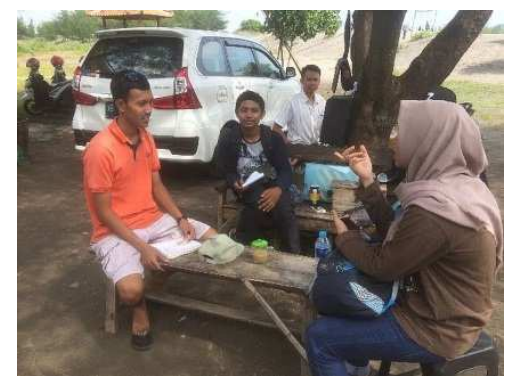

Fig. 6. The interview with the visitors of Sand Dunes Tourism. Source: Documentation of author, 2018.

The efforts and innovations to improve tourists's interest to visit the barchan sand dunes based on the interview are addition of the temporary infrastructure services and tour packages. The addition of infrastructure services is such as trade place with the local products, pre-wedding photo area, and ecotourismbased outbond area. the distribution of tour infrastructure of sand dunes can be looked at the recomended facilities of barchan sand dunes tourism map in Figure 7.

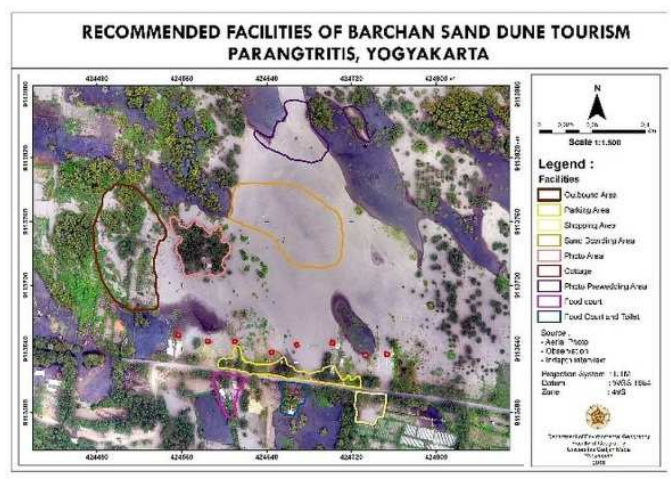

Fig. 7. Recommended facilities of Barchan Sand Dunes tourism map. Source: Data Proccessing Result, 2018

The recommendation of additional infrastructure is also in accordance with characteristics of touris attraction which are something to do, something to see, and something to buy [15]. Tourist attraction of barchan sand dunes have had the characteristic of something to see through the beauty and the uniqueness of the sand dunes, but there are not been the requirements yet of the optimal something to buy and something to see. The activity that can be done on the barchan sand dunes is sand boarding so that the supporting facilities are needed to optimize the income which can be gotten through prewedding photo area and ecoedutourism-based outbond area. the trade place of local products also needs to be added to introduce the local culture and to increase the income of Regosembilan Hamlet's community.

Based on the field observation and indepth interview, it is known that in the management of barchan sand dunes, the manager only depends on the benefit earned from visitors parking fees, sand boarding, and prewedding photo fees. The manager can only earns the fund from those 3 sources due to the development of 
barchan sand dunes also have to determine the environmental aspect which is the sustainability of sand dunes that become the uniqueness of tropical coast in Indonesia, in accordance with the law Number 27 year of 2007 about sand dnes as the special area and Governor law of D.I. Yogyakarta Number 115 year of 2015 about the preservation geological heritage area. The $10 \%$ of results of parking, sand boarding, and pre-wedding photo fees are used for the cost of sand dunes tourism management and cash village while the $90 \%$ of them are used for employee fees.

The recomendation related to the addition of potential factors that are expected can improve the tourists's interest based on Figure 7 divided into 3 components which are promotion optimization, infrastructure addition, and touris's interest improvement. Promotion optimization can be done through the creating of attractive sand dunes profile video and leaflet or poster which can be distributed massively in various media social such as Line, Instagram, and website. Those recomendation should be done due to the less intensive and interesting promotions.

The infrastructures which can be added are making the signpost to the barchan location, making the information board about barchan as an educational facility and also as the knowledge about the history of barchan development, the establishment of film studio about the barchan which is possible to cooperate with Parangtritis Geomaritime Science Park (PGSP), the addition of special trade area with local products that can grow the creative economy of community around the barchan sand dunes tourism, and addition outbond area. the addition of those infrastructures are expected to optimize the activities in barchan sand dunes tourism.

Tourist packages also becomes the recomendation for the development of barchan sand dunes. The addition of that option is based on the possibility of the improvement of the tourist's interest to the tourism attractives or in the other words, it is one of the marketing strategy to improve the tourist's interest to the Barchan Sand Dunes.

\section{Conclusion}

Projection result from calculation according to NPV formula as CBA analysis known that management of barchan sand dune in Parangtritis, Kretek, Bantul regency is feasible to continue until 2045 with estimated profit reached Rp648,000,000 but there is a decrease of level of efficiency then result calculations can be used as consideration in the management of sand dune tourism.

Recommendations for the development of barchan sand dune tourism include intensification and diversification of tourism. Intensification of tourism through spatial zoning with the addition of marketing strategy factors of barchan sand dune attractions. Spatial zoning in the form of recommendation map is focused on the division of tourist area within the supporting infrastructure unit of sand dune. Efforts to diversify through the addition of infrastructure and tourism interest in accordance with the principle of tourism in the form of something to do, something to see and something to buy. Addition to the marketing strategy factor of barchan sand dune object by considering the sustainability aspect of sand dune, possibly to be realized and of course the profit potential is aimed to realize sustainable tourism on the tourist object of sandstone barchan until 2045.

\section{References}

1. Putri, Ratih Fitria et al. Sand Dune Conservation Assessment in Coastal Area Using Alos Palsar DInSAR Technique. J. U. \& E. 11 (1) 9-29 (2017)

2. Duran, O. Schwammle V, Lind P G, \& Herrmann HJ. Size distribution and structure of Barchan dunefields. Copernicus Publications on behalf of the European Geosciences Union and the American Geophysical Union (2011)

3. Martinez, M. Luiza dan Norbert P. Psuty. Coastal Dune: Ecology and Conservation. Berlin: Springer (2008)

4. Marwasta, D. Pendampingan Masyarakat Desa Parangtritis dalam Pengelolaan Kawasan Gumuk Pasir Melalui Kegiatan Diversifikasi Usaha Berbasis Sumberdaya Pesisir. Yogyakarta. UGM: Fakultas Geografi (2014)

5. Suparmoko. 1989. Ekonomi Sumber Daya Alam dan Lingkungan: Suatu Pendekatan Teoritis. Yogyakarta: PAU-UGM

6. Suparmoko, M. Panduan dan Analisis Valuasi Ekonomi Sumberdaya Alam dan Lingkungan (Konsep, Metode Perhitungan, dan Aplikasi). Yogyakarta: BPFE (2009)

7. Aprilya, F.C., et al. Analisis Kelayakan Teknologi Informasi Menggunakan Metode Cost Benefit Analysis Dengan Microsoft Excel. J. I. 4 (2) (2010)

8. Dunn, William N. Analisis Kebijakan Publik. Yogyakarta: Universitas Gadjah Mada Press (2003)

9. Siegel, S. dan Shimp, T.A. Promotion Management and Marketing Communication. Florida: The Dryden Press (1994)

10. Sugiyono. Metode Penilaian. Bandung : Alfabeta (2011)

11. Purnamawati, Dwi Indah Ferdinandus Berdinandus, Analisis dan kekuatan Angin Pembentukan Barchan Dune dan Transveral Dune di Pantai Parangtritis, Provinsi DIY Berdasarkan Data Geologi. Prosiding Seminar Nasional. Aplikasi Sains dan Tekhnologi (SNAST) Periode III Yogyakarta (2012)

12. Sunarto, Geomorfologi Dan Kontribusinya Dalam Pelestarian Pesisir Bergumuk Pasir Aeolian Dari Ancaman Bencana Agrogenik Dan Urbanogenik. Naskah Pidato Pengukuhan Jabatan Guru Besar 2 April 2014. Yogyakarta: Fakultas Geografi. Universitas Gadjah Mada (2014)

13. Husnan, S., Suwarsono, Studi Kelayakan Proyeksi. Yogyakarta: Unit Penerbit dan Pencetak (UPP), AMP YKPN (1994) 
14. Commonwealth of Australia. Introduction to CostBenefit Analysis and Alternative Evaluation Methodologies. Department of Finance and Administration (2006)

15. Yoeti, O. Budaya Tradisional yang Nyaris Punah. Jakarta: Departemen Pendidikan dan Kebudayaan (1985) 